\title{
Review
}

\section{Mechanisms of HIV-associated lymphocyte apoptosis: 2010}

\author{
NW Cummins ${ }^{1}$ and AD Badley ${ }^{* 1}$
}

The inevitable decline of CD4T cells in untreated infection with the Human immunodeficiency virus (HIV) is due in large part to apoptosis, one type of programmed cell death. There is accumulating evidence that the accelerated apoptosis of CD4T cells in HIV infection is multifactorial, with direct viral cytotoxicity, signaling events triggered by viral proteins and aberrant immune activation adding to normal immune defense mechanisms to contribute to this phenomenon. Current antiviral treatment strategies generally lead to reduced apoptosis, but this approach may come at the cost of preserving latent viral reservoirs. It is the purpose of this review to provide an update on the current understanding of the role and mechanisms of accelerated apoptosis of T cells in the immunopathogenesis of HIV infection, and to highlight potential ways in which this seemingly deleterious process could be harnessed to not just control, but treat HIV infection.

Cell Death and Disease (2010) 1, e99; doi:10.1038/cddis.2010.77; published online 11 November 2010

Subject Category: Immunity

The chronic gradual loss of CD4 + T cells in untreated human immunodeficiency virus (HIV) infection, and the consequent adverse effects on both innate and adaptive immunity, lead to the opportunistic infections and malignancies characteristic of acquired immunodeficiency syndrome (AIDS). Loss of a cell type can occur by one of the three mechanisms: (1) decreased production; (2) increased destruction; or (3) redistribution (Figure 1a). In viral infections, increased destruction can occur by direct cytotoxicity of infected cells, programmed cell death (either apoptotic or non-apoptotic) triggered in infected cells, or programmed cell death in uninfected, so called 'bystander', cells triggered by soluble or membrane-bound viral or host immune factors. In fact, all of these mechanisms likely contribute to HIV immunopathogenesis (Figure 1b); however, the relative contribution of each mechanism in clinical HIV infection remains unclear.

There is controversy regarding the effect of HIV infection on thymic output, because a reliable measure of thymic output is lacking, and a full discussion of the controversy is beyond the scope of this review. Early studies indicated decreased T-cell production in the thymus in HIV infection due to a combination of direct cytopathicity of HIV-infected thymocyte precursors and apoptosis of uninfected immature thymocytes. This manifests as thymic atrophy, decreased circulating naïve CD4T cells, and decreased T-cell receptor rearrangement excision circles (TRECs) in circulating T cells in HIV infection. TREC content is inversely correlated with HIV viral load, and after initiation of effective antiretroviral therapy returns to levels comparable with uninfected controls. ${ }^{1}$ The usefulness of TREC content to quantify thymic output has been questioned, as mathematical models suggest that either division or death of naïve $T$ cells would artificially lower measured TREC content in the absence of decreased thymic output. However, by examining the ratio of late TRECs to early TRECs in peripheral $T$ cells as a marker of intrathymic proliferation, reduced intrathymic proliferation, and thus thymic output, is still evident in HIV infection compared with uninfected controls. ${ }^{2} \mathrm{HIV}$ also infects and induces apoptosis of CD34 + multipotent hematopoietic progenitor cells, thereby potentially decreasing progenitor cell input into the thymus.

Apoptosis of circulating CD4T cells has not been consistently found to correlate with HIV viral load. ${ }^{3}$ This suggests several possibilities: (1) not all of the CD4T-cell apoptosis is driven by active viral replication or the immune response to such; or (2) the circulating CD4T cells, although the easiest to quantify, are not necessarily the most physiologically relevant compartment to gauge functional CD4T-cell loss. Both of these possibilities are supported by one early investigation of apoptosis in lymph nodes of HIV-infected persons that showed increased apoptosis compared with uninfected persons; and in that study, the majority of the apoptotic cells, defined by terminal deoxynucleotidyl transferase-mediated dUTP nick end labeling (TUNEL) staining positivity, were not demonstrated to be infected. ${ }^{4}$ However, some have questioned

\footnotetext{
${ }^{1}$ Division of Infectious Diseases, Mayo Clinic, Rochester, MN, USA

*Corresponding author: AD Badley, Division of Infectious Diseases, Mayo Clinic, 200 First Street SW, Guggenheim 5, Rochester, MN 55905, USA. Tel: 507 284-2028; Fax: 507284 3757; E-mail: badley.andrew@mayo.edu

Keywords: HIV; apoptosis; immunopathogenesis; T-cell

Abbreviations: AICD, activation-induced cell death; AIDS, acquired immunodeficiency syndrome; DR, death receptor; HIV, human immunodeficiency virus; IFN, interferon; LTNP, long-term non-progressor; LTR, long terminal repeat; NK, natural killer; PBL, peripheral blood lymphocyte; PBMC, peripheral blood mononuclear cell; SIV, simian immunodeficiency virus; TRAIL, tumor necrosis factor-related apoptosis-inducing ligand; TREC, T-cell receptor excision circle; TUNEL, terminal deoxynucleotidyl transferase-mediated dUTP nick end labeling

Received 28.6.10; accepted 24.8.10; Edited by M Piacentini
} 

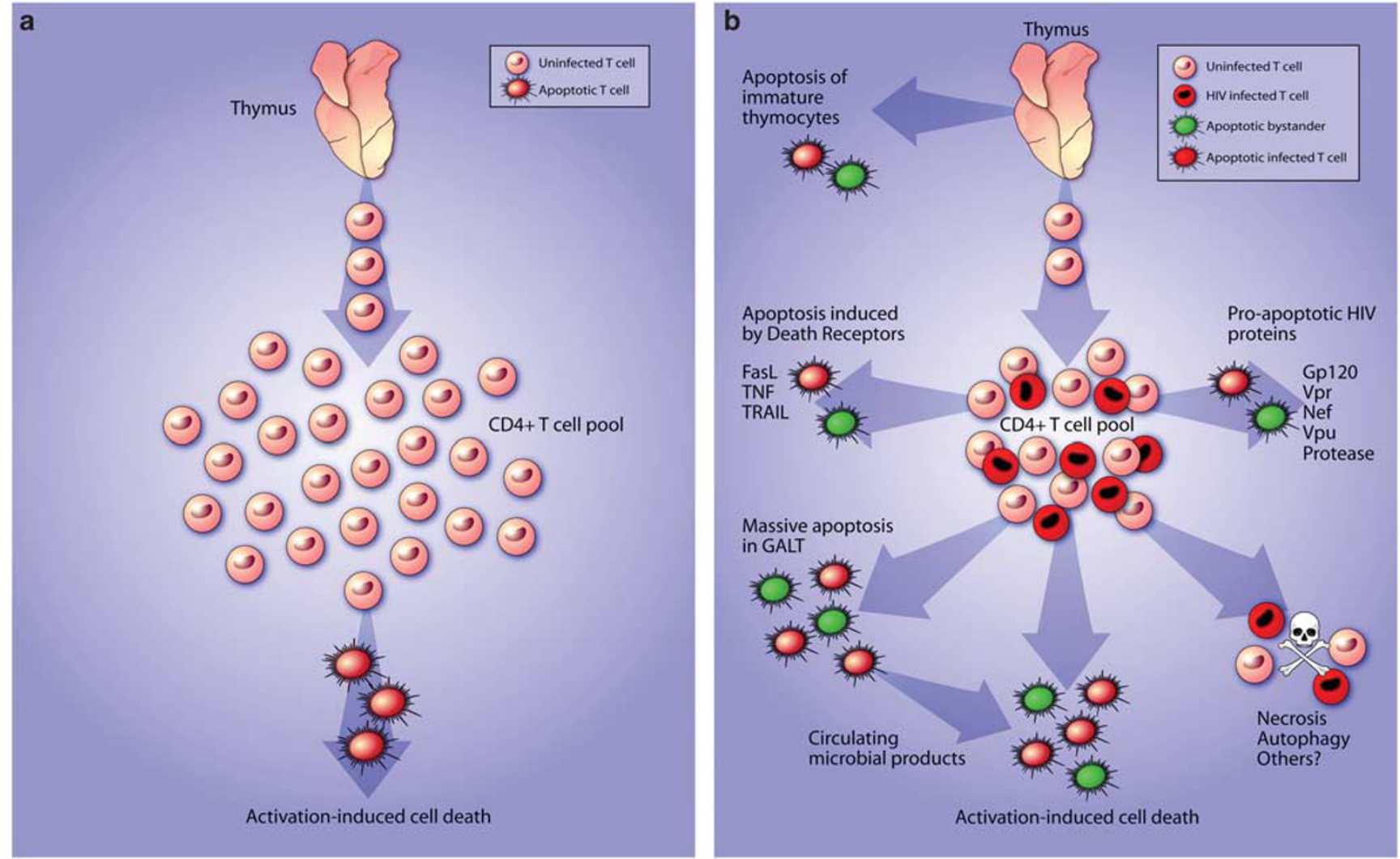

Figure 1 (a) Simplified diagram of normal CD4 + T-cell homeostasis. The peripheral CD4 + T-cell pool is maintained through a balance of thymopoiesis and activationinduced cell death. (b) Mechanisms of CD4 + T-cell death in untreated HIV infection. The peripheral CD4 + T-cell pool is depleted through decreased thymopoiesis and excessive apoptosis through multiple HIV viral-specific and non-specific mechanisms

the methods used to determine infection in that study. Specifically, infected cells were defined by in situ hybridization of riboprobes more than $2 \mathrm{kbp}$ in length, which are likely to be degraded in TUNEL-positive cells. The accelerated apoptosis in HIV-infected lymph nodes affects all functional compartments of the node, and is not limited to just CD4T cells, but also affects CD8 $+\mathrm{T}$ cells and $\mathrm{B}$ cells, supporting the argument for both viral and non-viral factors in enhancing apoptosis. The importance of apoptosis of CD4T cells in gutassociated lymphoid tissue will be discussed below.

Redistribution, with CD4T-cell sequestration in secondary lymphoid organs, may play an important role in CD4T-cell decline in HIV infection. Resting CD4T cells, which are not permissive of HIV infection, exposed to HIV upregulate CD62L surface expression, potentially leading to accumulation in lymph nodes and exposure to proapoptotic signals. ${ }^{5}$ CD4 + CD25 + FoxP3 + regulatory T cells when exposed to HIV upregulate CD62L, possibly contributing to immunosuppression by homing to lymph nodes. Increased splenic sequestration and apoptotic death of a subset of memory $T$ cells expressing CCR 6 has been demonstrated in progressive HIV disease. ${ }^{6}$

\section{Correlations between Retroviral-induced Apoptosis and Immunodeficiency}

In an attempt to discern the how and why of apoptosis in HIV disease, one must begin with the origin of the virus itself.
HIV infection is the result of episodes of cross-species, zoonotic transmission of simian immunodeficiency viruses (SIVs) from African non-human primates. In natural infection of non-human primates, such as sooty mangabeys, with their species-specific strain of SIV, progressive CD4T-cell declines because of apoptosis, and manifestations of secondary immunodeficiency usually do not occur despite often robust and chronic viral replication. ${ }^{7}$ However, non-human primate models of infection in which a strain of SIV is introduced into a non-natural host often result in CD4T-cell decline and AIDSlike manifestations. Recent evidence, though, suggests that SIVcpz infection of chimpanzees in the wild is indeed pathogenically associated with increased mortality and CD4T-cell loss, and may be an exception to this general rule. The role of apoptosis in SIV disease has been reviewed extensively elsewhere. ${ }^{8}$ Pandrea et al. have offered a comprehensive model to explain why natural SIV infection does not generally lead to disease progression, whereas pathogenic HIV and SIV infections do. They propose that the presence of acute and chronic inflammatory states, loss of enteric CD4T cells, and increased T-cell apoptosis and proliferation that occur in pathogenic SIV infection are the determining factors in disease progression. ${ }^{8}$ This model is supported by recent observations that pathogenic lentiviral infections are associated with chronic-sustained immune activation and expression of interferon (IFN)-responsive genes, including tumor necrosis factor-related apoptosisinducing ligand (TRAIL), whereas non-pathogenic infections 
are not. ${ }^{9}$ Further differences between HIV infection and non-pathogenic SIV infection, as they relate to mechanisms of CD4T-cell apoptosis, are discussed below.

It has long been recognized that some humans infected with HIV, much like non-human primates with natural SIV infection, do not develop progressive CD4T-cell decline and progressive disease despite ongoing viral replication, so called longterm non-progressors (LTNPs). Rates of in vitro spontaneous apoptosis of CD4T cells in LTNPs are less than in patients with progressive disease, and approximate those in uninfected controls. Inconsistent results, however, have been obtained with mitogen-induced apoptosis. Some clues to why there is decreased apoptosis in LTNPs compared with progressors include: decreased T-cell Fas sensitivity; ${ }^{10}$ higher frequency of infection with virus with a Vpr R77Q mutation; ${ }^{11}$ and decreased expression of IFN $\alpha$, TRAIL, and death receptor 5 (DR5) in lymphoid tissues. ${ }^{12}$

It is possible that apoptosis affects the four subtypes of CD4T cells to different degrees in HIV infection, and that this differential susceptibility could contribute to the immunodeficiency associated with infection; however, this has not been definitively studied. It was recognized early that HIV infection in vivo is associated with an abnormal shift toward a predominately Th2 phenotype. Although both Th1 and Th2 cells are susceptible to Fas-mediating apoptosis, ${ }^{13}$ one of the key players in HIV infection discussed below, Th1 cells when compared with Th2 cells, are more likely to be productively infected, and are more susceptible to activation-induced cell death. ${ }^{13}$ On the other hand, CD4 + CD25 + FoxP3 + regulatory $\mathrm{T}$ cells, when exposed to HIV in vitro, do not undergo apoptosis. ${ }^{14}$ Furthermore, in SIV-infected rhesus macaques, mucosal regulatory $T$ cells have lower apoptosisrelated gene expression than non-regulatory $T$ cells and are spared from SIV-mediated cell death. ${ }^{15}$ Circulating and mucosal Th17 cells are decreased in HIV-infected patients compared with uninfected controls, ${ }^{16}$ whereas SIV-infected sooty mangabeys maintain normal levels of Th17 cells. ${ }^{16}$ Notably, Th17 cells from HIV-infected patients are similarly susceptible to activation-induced cell death (AICD) as Th1 cells. ${ }^{16}$ Despite these suggestive lines of evidence, no single study to date has compared markers of apoptosis across the four subtypes of CD4T cells in HIV-infected patients.

\section{Mediators of Apoptosis in HIV Disease}

Apoptosis may be stimulated by environmental stress, toxins, removal of growth factors, or by one of the three deathinducing ligands - tumor necrosis factor, FasL and TRAIL. The roles of each of these mediators in HIV disease, and their potential for targeted immunotherapy, will be discussed briefly below.

Fas/FasL. The role of Fas/FasL interactions in the immunopathology of HIV infection has been studied extensively and reviewed elsewhere. ${ }^{17}$ In brief, both soluble and membrane-bound Fas and FasL levels are elevated in HIV-infected patients compared with uninfected patients and correlate with disease progression. ${ }^{18}$ In HIV-infected patients, Fas expression is increased in CD4 and CD8positive $T$ cells and $B$ cells, and Fas $L$ expression is increased on monocytes, macrophages and natural killer (NK) cells, both in the peripheral circulation and the lymph nodes. ${ }^{19}$ Microarray analysis of gene expression in lymph nodes from HIV-infected patients confirms increased Fas/FasL. ${ }^{20}$

HIV-infected cells are more susceptible to Fas-mediated apoptosis in vitro compared with uninfected cells, but they do not make up the majority of apoptotic cells in vivo, ${ }^{21}$ and the majority of circulating apoptotic peripheral blood mononuclear cells (PBMCs) from HIV-infected patients do not express Fas. ${ }^{22}$ HIV-infected macrophages are able to induce apoptosis in $T$ cells from HIV-infected donors, but not from HIV-uninfected donors, in vitro through Fas/FasL. ${ }^{21}$ These observations contribute to the 'bystander effect' hypothesis that proposes that most of the apoptotic cell death occurring in HIV infection involves uninfected cells responding to infection in lymphoid tissues.

Interestingly, T cells from chimpanzees infected with HIV do not undergo apoptosis through Fas ligation. ${ }^{23}$ However, cynomolgus monkeys infected with pathogenic SIV/HIV-C2/1 have increased expression of Fas on CD4 and CD8T cells, and FasL on $\mathrm{T}$ and $\mathrm{B}$ cells compared to before infection. ${ }^{24}$ Non-progressing patients have significantly lower serumsoluble Fas concentrations, decreased lymphocyte expression of Fas and FasL, and decreased Fas-sensitivity ${ }^{10}$ than progressing patients. How the HIV virus influences Fas/FasL expression will be discussed below. Inhibiting the Fas pathway with a blocking monoclonal antibody to FasL during the acute phase of SIV infection in macaques attenuated disease progression in one study. ${ }^{25}$ There have been no human trials of Fas/FasL agonists or antagonists in the treatment of HIV infection to date because of significant toxicities in pre-clinical studies.

Tumor necrosis factor- $\alpha$. The important role of TNF $\alpha$ in the pathogenesis of HIV infection and its associated complications, particularly enhancing viral replication and mediating apoptosis of CD4T cells, has been studied extensively and recently reviewed elsewhere. ${ }^{26}$ Table 1 summarizes the results of the prospective trials performed with the TNF $\alpha$ inhibitors, pentoxifylline, ketotifen, thalidomide and etanercept. Overall, no significant beneficial immunologic effect has been demonstrated with specific inhibition of $\mathrm{TNF} \alpha$; and several of the agents have significant adverse effects, including a paradoxical increase of the HIV viral load.

On the other hand, recombinant TNF $\alpha$ has been investigated in preclinical and phase $\mathrm{I} / \mathrm{II}$ trials with the goal of clearing latently infected cells, but is unlikely to be a clinically useful option because of significant-related toxicities. ${ }^{27}$

TRAIL. TRAIL is a member of the TNF superfamily that has been implicated in mediating apoptosis of CD4T cells in HIV infection through its interactions with its death-inducing receptors, DR4 and DR5, on infected and uninfected $T$ cells. HIV infection of CD4T cells results in increased expression of TRAIL and DR5 compared with uninfected cells. $^{28}$ HIV infection of dendritic cells and macrophages results in increased expression of TRAIL, which can then induce apoptosis in uninfected bystander T cells. ${ }^{29}$

HIV-infected patients have elevated serum levels of TRAIL $^{28}$ and increased expression of DR5 on circulating 
Table 1 Studies on modulation of death-receptor-mediated apoptosis in HIV infection

\begin{tabular}{|c|c|c|c|c|}
\hline Agent & Mechanism of action & Dose & Clinical outcomes assessed & Clinical effects \\
\hline \multicolumn{5}{|c|}{ Clinical studies on TNF inhibitors } \\
\hline \multirow[t]{7}{*}{ Pentoxifylline } & $\begin{array}{l}\text { Antagonist - blocks } \\
\text { TNF } \alpha \text {-induced activation } \\
\text { of NF- } \kappa \mathrm{B}\end{array}$ & $400 \mathrm{mg}$ TID orally for 8 weeks & TNF expression and HIV viral load & $\begin{array}{l}\text { Decreased TNF expression; no effect } \\
\text { on HIV replication }\end{array}$ \\
\hline & & $400 \mathrm{mg}$ TID orally for 12 weeks & TNF expression and HIV viral load & $\begin{array}{l}\text { Decreased TNF and HIV viral load in } \\
\text { AZT- and PTX-treated patients } \\
\text { compared with either agent or alone }\end{array}$ \\
\hline & & 800 mg TID orally for 8 weeks & TNF expression and HIV-viral load & $\begin{array}{l}\text { Decreased TNF expression; no effect } \\
\text { on HIV replication }\end{array}$ \\
\hline & & $800 \mathrm{mg}$ TID orally for 6 weeks & $\begin{array}{l}\text { TNF expression; cellular immune } \\
\text { responses; fever, weight, fatigue, } \\
\text { and well-being. }\end{array}$ & No effects. Increased GI side effects. \\
\hline & & $400 \mathrm{mg}$ TID orally for 16 weeks & $\begin{array}{l}\text { CD4 count; mitogen-stimulated } \\
\text { cytokine production; HIV-viral load }\end{array}$ & $\begin{array}{l}\text { Transient improvements in CD4 } \\
\text { count, viral load, and cytokine } \\
\text { production. }\end{array}$ \\
\hline & & $1.5 \mathrm{mg} / \mathrm{min}$ intravenously for $6 \mathrm{~h}$ & $\begin{array}{l}\text { Dose tolerance and ex vivo LPS- } \\
\text { induced TNF production }\end{array}$ & $\begin{array}{l}\text { No effect on TNF } \alpha \text { production at } \\
\text { maximally tolerated dose }\end{array}$ \\
\hline & & $\begin{array}{l}400 \mathrm{mg} \text { TID orally for } 24 \text { weeks } \\
400 \mathrm{mg} \text { TID orally for } 6-20 \\
\text { months }\end{array}$ & $\begin{array}{l}\text { Caspases } 1 \text { and } 8 \text { levels in blood } \\
\text { Symptoms and CD } 4 \text { counts }\end{array}$ & $\begin{array}{l}\text { Decreased caspases } 1 \text { and } 8 \text { levels } \\
\text { Improved symptoms and weight; } \\
\text { transient increase in CD } 4 \text { count }\end{array}$ \\
\hline Ketotifen & $\begin{array}{l}\text { Antagonist }- \text { inhibits } \\
\text { TNF } \alpha \text { release from } \\
\text { PBMCs }\end{array}$ & 4 mg daily orally for 84 days & $\begin{array}{l}\text { Body composition; TNF } \alpha \text { release } \\
\text { from PBMCs and serum } \\
\text { concentrations }\end{array}$ & $\begin{array}{l}\text { Transient weight gain; inhibited TNF } \alpha \\
\text { release from stimulated PBMCs but } \\
\text { no difference in serum levels }\end{array}$ \\
\hline \multirow[t]{4}{*}{ Thalidomide } & $\begin{array}{l}\text { Antagonist - } \\
\text { decreases TNF } \alpha \\
\text { expression }\end{array}$ & 100 mg QID orally for 12 weeks & $\begin{array}{l}\text { Weight gain, CD4 count, and } \\
\text { viral load }\end{array}$ & $\begin{array}{l}\text { Improved weight gain, no change } \\
\text { in viral load, or CD4 count }\end{array}$ \\
\hline & & $\begin{array}{l}200 \mathrm{mg} \text { once daily orally for } \\
4 \text { weeks }\end{array}$ & $\begin{array}{l}\text { Oral ulcer resolution, QOL, plasma } \\
\text { TNF } \alpha \text {, and TNF } \alpha \text { receptors, } \\
\text { HIV-viral load }\end{array}$ & $\begin{array}{l}\text { Increased oral ulcer resolution; } \\
\text { unexpected increases in plasma } \\
\text { TNF } \alpha \text {, soluble TNF } \alpha \text { receptors, and } \\
\text { HIV-viral load }\end{array}$ \\
\hline & & 100 mg daily orally for 24 weeks & $\begin{array}{l}\mathrm{CD} 4 \text { count, TNF } \alpha \text {, and TNF } \alpha \\
\text { receptor levels }\end{array}$ & No significant clinical effects noted \\
\hline & & 200 mg daily orally for 4 weeks & $\begin{array}{l}\text { Immune activation, TNF } \alpha \text { levels } \\
\text { and HIV-viral load }\end{array}$ & $\begin{array}{l}\text { No effect on TNF } \alpha \text {; increase in HIV } \\
\text { viral-load and immune activation }\end{array}$ \\
\hline \multirow[t]{2}{*}{ Etanercept } & $\begin{array}{l}\text { Antagonist - soluble } \\
\text { p75 TNF receptor: } \\
\text { Fc fusion protein }\end{array}$ & $\begin{array}{l}10 \mathrm{mg} \text { intravenous infusion } \\
\text { once in combination with } \\
\text { HAART and rlL2 }\end{array}$ & $\begin{array}{l}\text { HIV-viral load, serum levels of } \\
\text { proinflammatory cytokines }\end{array}$ & $\begin{array}{l}\text { No changes in already suppressed } \\
\text { TNF and viral load; decrease in IL6 } \\
\text { and CRP levels }\end{array}$ \\
\hline & & $\begin{array}{l}25 \mathrm{mg} \text { intravenously twice } \\
\text { weekly for } 4 \text { weeks }\end{array}$ & $\begin{array}{l}\text { Clinical response to antituberculous } \\
\text { therapy, CD4 count, and viral load }\end{array}$ & $\begin{array}{l}\text { Non-significant trend in improved } \\
\text { responses to antituberculous therapy } \\
\text { and improvements in CD4 count } \\
\text { without change in HIV-viral load }\end{array}$ \\
\hline \multicolumn{5}{|l|}{$\begin{array}{l}\text { Preclinical studies } \\
\text { on fas inhibitors }\end{array}$} \\
\hline $\begin{array}{l}\text { Monoclonal } \\
\text { antibody to } \\
\text { FasL }\end{array}$ & $\begin{array}{l}\text { Antagonist - blocks } \\
\text { Fas/FasL interaction }\end{array}$ & $\begin{array}{l}4 \mathrm{mg} / \mathrm{kg} \text { intravenously one } \\
\text { week before, at the time of, } \\
\text { and } 1,2 \text {, and } 3 \text { weeks after } \\
\text { acute } \\
\text { SIVmac infection }\end{array}$ & $\begin{array}{l}\text { B and T-cell death, cytotoxic } \\
\text { T lymphocyte and antibody } \\
\text { responses, } \\
\text { viral set point }\end{array}$ & $\begin{array}{l}\text { Attenuated acute SIVmac disease } \\
\text { and improved survival }\end{array}$ \\
\hline \multicolumn{5}{|c|}{ In vitro studies on TRAIL } \\
\hline $\begin{array}{l}\text { Leucine-zipper } \\
\text { recombinant } \\
\text { human TRAIL }\end{array}$ & Agonist & $1 \mu \mathrm{g} / \mathrm{ml}$ for $12 \mathrm{~h}$ & $\begin{array}{l}\text { Viral RNA, proviral DNA, and p24 } \\
\text { antigen production in PBMCs from } \\
\text { HIV-infected patients treated ex vivo }\end{array}$ & $\begin{array}{l}\text { Increased apoptosis and decreased } \\
\text { viral RNA, proviral DNA, and p24 } \\
\text { antigen production }\end{array}$ \\
\hline $\begin{array}{l}\text { Recombinant } \\
\text { human TRAIL }\end{array}$ & Agonist & $5 \mathrm{ng} / \mathrm{mL}$ & $\begin{array}{l}\text { Recoverable virus from PBMCs from } \\
\text { HIV-infected, -suppressed patients } \\
\text { treated ex vivo with TRAIL }\end{array}$ & $\begin{array}{l}\text { Decreased recoverable virus from } \\
\text { latently infected PBMCs }\end{array}$ \\
\hline $\begin{array}{l}\text { Mapatumumab, } \\
\text { Lexatumumab }\end{array}$ & $\begin{array}{l}\text { Monoclonal } \\
\text { agonistic antibodies to } \\
\text { TRAIL receptors }\end{array}$ & $3 \mu \mathrm{g} / \mathrm{mL}$ & $\begin{array}{l}\text { Apoptosis of PBLs from HIV-infected } \\
\text { patients treated ex vivo }\end{array}$ & $\begin{array}{l}\text { No effect on apoptosis in ex vivo } \\
\text { PBMCs from HIV-infected patients. }\end{array}$ \\
\hline $\begin{array}{l}\text { Monoclonal } \\
\text { antibody to } \\
\text { TRAIL }\end{array}$ & Antagonist & $\begin{array}{l}1 \mathrm{mg} \text { intraperitoneally } 9 \text { days } \\
\text { after HIV infection }\end{array}$ & $\begin{array}{l}\text { Apoptosis of CD4 T cells in human } \\
\text { PBL-transplanted NOD-SCID }\end{array}$ & Decreased CD4 T-cell apoptosis. \\
\hline
\end{tabular}

Abbreviations: AZT, azidothymidine; CRP, C-reactive protein; GI, gastrointestinal; HIV, human immunodeficiency virus; NOD-SCID, non-obese-severe-combined immunodeficiency mice; PBLs, peripheral blood lymphocytes; PBMCs, peripheral blood mononuclear cells; PTX, pentoxifylline; QID, four times daily; QOL, quality of life; SIV, simian immunodeficiency virus; TID, three times daily; TNF, tumor necrosis factor; TRAIL, TNF-related apoptosis-inducing ligand 
PBMCs compared with uninfected patients. Plasmacytoid dendritic cells from HIV-infected, viremic patients express TRAIL and are able to induce apoptosis in uninfected but not infected CD4T lymphocytes. HIV-infected patients also demonstrate elevated TRAIL and DR5 in lymphoid tissues. ${ }^{30}$ Initiation of HAART in infected patients decreases serum TRAIL levels, as well as TRAIL and DR5 expression on circulating CD4T cells. ${ }^{28,30}$ However, in lymphoid tissues, infected patients on HAART exhibit decreased TRAIL expression, but not DR5 expression, compared with untreated infected patients. ${ }^{30}$ In a mouse model of HIV infection using human peripheral blood lymphocyte (PBL)-transplanted non-obese diabetic severe-combined immunodeficiency mice, treatment with neutralizing anti-TRAIL monoclonal antibody decreased CD4T-cell apoptosis compared with untreated infected animals. ${ }^{31}$

Treatment of HIV-infected PBLs and monocyte-derived macrophages with recombinant TRAIL results in decreased HIV burden compared with control-treated cells in vitro, suggesting this might be an approach for therapy. ${ }^{32}$ Recombinant human TRAIL and agonistic monoclonal antibodies to DR4 and DR5 are currently in phases I and II clinical trials for cancer chemotherapy where induction of apoptosis in malignant cells is the goal of the therapy. A theoretical concern of TRAIL agonist therapy in HIV disease is that although HIV-infected cells may be killed by such therapy, uninfected bystander $\mathrm{T}$ cells may also undergo apoptosis, thereby, worsening immune suppression. However, treatment of PBLs from HIV-infected patients in vitro with recombinant human TRAIL decreases recoverable virus without a detectable change in quantity or function of the lymphocytes. ${ }^{33}$

Chronic immunologic stimulation in HIV disease. After responding to any neoantigen, contraction of previously expanding immune cell populations is necessary; one mechanism that is used is the induction of apoptosis of activated immune cells - activation induced cell death (AICD). Widespread and chronic activation of the immune system during HIV infection is characterized by generalized lymphadenopathy, increased circulating levels of $B$ lymphocytes, activated T lymphocytes, NK cells, antigenpresenting cells, hypergammaglobulinemia and other serum markers of immune activation in HIV-infected patients compared with uninfected patients. The contribution of chronic immunologic stimulation to HIV pathogenesis is supported by observations of circulating activated (HLA$\mathrm{DR}+)$ monocytes and activated $(\mathrm{CD} 38+)$ CD8T cells correlating with CD4T-cell loss and disease progression. ${ }^{34}$ Chronic immunologic stimulation leads to AICD in CD4T cells via both death receptor (Fas)-dependent and -independent mechanisms. However, the increased AICD seen in HIV disease is not limited to CD4T cells, as it is hypothesized to contribute to CD8T-cell exhaustion as well, a process that may be associated with the expression of programmed death-1 (PD-1) on activated CD8T cells in HIV-infected patients. ${ }^{35}$

The sources of chronic immunologic stimulation in HIV are multiple and can include persistent viral replication, effects of circulating HIV proteins and virus like particles, opportunistic infections, and reactivation of other latent viral infections. Also, absolute counts of regulatory $T$ cells decrease over time in progressive HIV infection, and this correlates with immune activation. ${ }^{36}$ Recent attention has focused on the depletion of CD4T cells in the gastrointestinal tract, leading to increased microbial translocation and circulation of microbial cellular components, including lipopolysaccharide and bacterial DNA, the levels of which correlate with HIV disease progression. ${ }^{37}$ Systemic exposure to microbial by-products could lead to activation through Toll-like receptor signaling, thereby promoting AICD and contributing to the loss of CD4T cells outside of the Gl tract. ${ }^{38}$ Systemic microbial by-products may also inhibit T-cell expansion and function by upregulating PD-1 expression and IL-10 production by monocytes. ${ }^{39}$

Pharmacological attempts at modulating immune activation in HIV disease with the goal of increasing CD4T cells counts with corticosteroids, cyclosporine, cyclooxygenase 2 inhibitors, mycophenolate mofetil and chloroquine have either been unsuccessful or demonstrated only modest benefits in shortterm surrogate endpoints.

HIV proteins and apoptosis. Many of the proteins that are encoded by the HIV genome, including gp120, Tat, Nef, Vpr, Vpu and HIV protease, have been found to have pro- and/or antiapoptotic qualities (listed in Table 2 and depicted in Figure 2). Each of these proteins will be reviewed below. It is important to note that the actual in vivo concentrations of these proteins seen in HIV infection are largely unknown, and that in vitro experiments involving overexpression of a particular protein, or exogenous treatment with high protein concentrations, may not be truly reflective of in vivo effects.

Gp120 and apoptosis. Gp120 is the glycoprotein expressed on the HIV envelope that binds to the CD4 receptor and either CXCR4 or CCR5 coreceptors facilitating viral attachment and, along with Gp41, entry into the cell. Both membrane-bound and soluble gp120 binding to CD4 leads to apoptosis of infected and uninfected CD4T cells. However, ligation with CD4 is not required, and of the coreceptors, gp120 signaling through CXCR4 is a more potent apoptotic stimulus than CCR5. Several mechanisms have been proposed for gp120's proapoptotic effect, including through upregulation of Fas, FasL, and TNF $\alpha$ expression; ${ }^{40}$ molecular mimicry with Fas; ${ }^{41}$ upregulation of TRAIL receptors DR4 and DR5; ${ }^{42}$ induction of cell cycle arrest at the $\mathrm{G} 2$ phase; ${ }^{43}$ generation of reactive oxygen intermediates; 44 reduced expression of $\mathrm{Bcl}-2 ;{ }^{45}$ phosphorylation of mTOR and p53; ${ }^{46}$ increased expression of the proapoptotic protein PUMA $;{ }^{47}$ and activation of $p 38 .{ }^{48}$ Membrane-bound Gp120 may also induce apoptosis through syncytia formation, although the role of syncytia formation in in vivo infection is controversial.

Although it is currently unclear which of these potential mechanisms predominates in in vivo HIV infection, it is clear that Gp120 is pluripotent, able to induce apoptosis in other types of cells, including CD8T cells, neurons, human vascular endothelial cells, cardiomyocytes, proximal renal tubular cells, hepatocytes, oral keratinocytes, lung endothelial cells, breast cancer cells, osteoblasts, and prostate cancer cells.

Tat and apoptosis. The HIV-1 transactivator protein, Tat, that promotes HIV-LTR (long terminal repeat) transcription 
Table 2 HIV encoded proteins and their reported pro- and antiapoptotic impact

\begin{tabular}{|c|c|c|}
\hline Protein & $\begin{array}{l}\text { Pro- or } \\
\text { antiapoptotic }\end{array}$ & Reported mechanisms \\
\hline Gp120 & Proapoptotic & $\begin{array}{l}\text { Molecular mimicry with Fas } \\
\text { Upregulation of Fas, FasL, and } \\
\text { TNF } \alpha \text { expression } \\
\text { G2 cell cycle arrest } \\
\text { Generation of reactive oxygen species } \\
\text { Downregulation of Bcl-2 expression } \\
\text { Phosphorylation of mTOR and p53 } \\
\text { Upregulation of PUMA expression } \\
\text { Upregulation of TRAIL-R1 and -R2 } \\
\text { Induction of syncytia formation } \\
\text { Activation of p38 }\end{array}$ \\
\hline \multirow[t]{2}{*}{ Tat } & Proapoptotic & $\begin{array}{l}\text { Upregulation of FasL expression } \\
\text { Upregulation of Bax expression } \\
\text { Upregulation of caspase } 8 \text { expression } \\
\text { Microtubule alteration } \\
\text { Oxidative stress } \\
\text { Upregulation of RCAS-1 expression }\end{array}$ \\
\hline & Antiapoptotic & $\begin{array}{l}\text { Decreased susceptibility to TNF } \alpha \text { and Fas } \\
\text { Upregulation of Bcl-2 expression } \\
\text { Decreased susceptibility to TRAIL } \\
\text { Downregulation of caspase } 10 \\
\text { expression } \\
\text { Upregulation of c-FLIP expression }\end{array}$ \\
\hline Vpu & Proapoptotic & $\begin{array}{l}\text { Increased susceptibility to Fas } \\
\text { Inhibition of NF- } \kappa \text { B }\end{array}$ \\
\hline \multirow[t]{2}{*}{ Nef } & Proapoptotic & $\begin{array}{l}\text { Upregulation of Fas and FasL expression } \\
\text { Downregulation of Bcl-2 and Bcl-XL } \\
\text { expression } \\
\text { Lysosomal permeabilization and } \\
\text { Cathepsin-D release } \\
\text { Upregulation of PD-1 }\end{array}$ \\
\hline & Anti-apoptotic & $\begin{array}{l}\text { Inhibition of ASK-1 } \\
\text { Inhibition of Bad } \\
\text { Inhibition of p53 }\end{array}$ \\
\hline \multirow[t]{2}{*}{ Vpr } & Pro-apoptotic & $\begin{array}{l}\text { Binding to ANT/VDAC leading to } \\
\text { mitochondrial depolarization } \\
\text { Binding to Bax leading to mitochondrial } \\
\text { depolarization }\end{array}$ \\
\hline & Anti-apoptotic & $\begin{array}{l}\text { Suppression of NF- } \kappa \mathrm{B} \text { proinflammatory } \\
\text { cytokine production } \\
\text { Upregulation of } \mathrm{Bcl}-2 \text { and downregulation } \\
\text { of Bax expression }\end{array}$ \\
\hline Protease & Pro-Apoptotic & $\begin{array}{l}\text { Cleavage of } \mathrm{Bcl}-2 \\
\text { Cleavage of Caspase } 8 \text { creating } \\
\text { pro-apoptotic Casp8p } 41\end{array}$ \\
\hline
\end{tabular}

has pleiotropic effects on apoptosis of CD4T cells. Tat is produced early in the life cycle of the virus, but also is secreted by infected cells and taken up by uninfected $T$ cells via clathrin-mediated endocytosis. ${ }^{49}$ Both pro- and antiapoptotic effects have been demonstrated in vitro, depending upon cell lines used, use of endogenous expression vectors or exogenous administration, dose of Tat administered, whether the cell is infected or not, and oxygen level. Treatment of uninfected Jurkat T-cell lines with low doses (pM) of Tat results in apoptotic resistance to TNF, Fas $^{50}$ and TRAIL, ${ }^{51}$ decreased expression of caspase $10,{ }^{52}$ and increased expression of Bcl-2 and C-FLIP ${ }^{52}$ compared with untreated cells. However, treatment of uninfected T-cell lines and PBMCs with higher doses (nM-MM) of Tat can increase FasL, ${ }^{53}$ caspase $8,{ }^{54} \mathrm{Bax}^{55}$ and RCAS-1 ${ }^{56}$

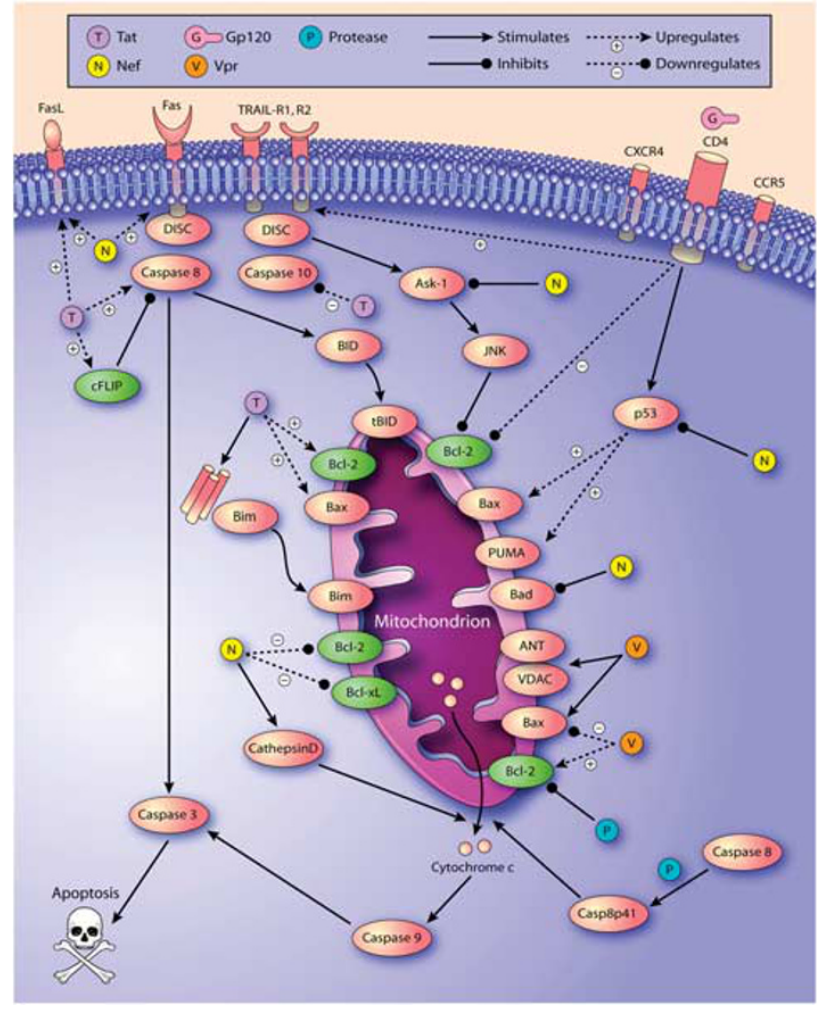

Figure 2 This figure depicts select interactions of HIV proteins with the mitochondrial pathway of apoptosis demonstrated in in vitro studies, demonstrating the both complexity and duplicity of these pathways. Which of these potential mechanisms occurs in vivo, and the relative importance, though, is less clear

expression, and cause oxidative stress ${ }^{57}$ compared with untreated cells. Tat can also bind to tubulin, resulting in microtubule alteration and Bim-mediated mitochondriadependent apoptosis. ${ }^{58}$

The role of Tat in inducing or inhibiting CD4T-cell apoptosis in vivo is unclear. Tat is present in concentrations in the serum of HIV-infected patients approximating the in vitro antiapoptotic doses. ${ }^{59}$ On the other hand, HIV infection of human monocytes and macrophages, or treatment with exogenous Tat, results in upregulation of TRAIL expression in these cells, which can then induce apoptosis in uninfected bystander T cells. ${ }^{60}$ Interestingly, chimpanzee $T$ cells treated with exogenous Tat are resistant to Tat-mediated apoptosis, ${ }^{61}$ and macrophages from chimpanzees, sooty mangabeys and African green monkeys do not upregulate TRAIL expression in response to Tat. $^{62}$

Vpu and apoptosis. Vpu is an HIV-encoded accessory protein that downregulates the CD4 receptor, thereby preventing superinfection of infected cells and allowing efficient budding of newly produced virus. Vpu may also play a significant role in CD4T-cell apoptosis in HIV infection. In vitro overexpression of $\mathrm{Vpu}$ in Jurkat $\mathrm{T}$ cells increases susceptibility to Fas-mediated apoptosis. ${ }^{63}$ This may be because expression of $\mathrm{Vpu}$ in HIV-infected or -transfected cells inhibits NF- $\kappa$ B-mediated expression of antiapoptotic genes. ${ }^{64}$ Deletion of Vpu from an HIV NL4-3 proviral construct significantly decreases CD4T-cell depletion in ex vivo-infected human lymphoid tissue compared with 
the wild-type parent virus. ${ }^{65}$ Interestingly, in the SHIV/ pig-tailed macaque model of HIV infection, Vpu proteins from different HIV-1 subtypes are associated with different rates of CD4T-cell loss over time, arguing for a pathogenic effect in vivo. ${ }^{66}$

Nef and apoptosis. Nef is a multifunctional HIV-encoded protein expressed early in the life cycle of the virus, responsible for downregulating CD4 receptor and $\mathrm{MHC}-\mathrm{I}$ expression as well as enhancing viral replication. Nefexpressing $\mathrm{T}$ cells demonstrate upregulated $\mathrm{Fas}$ and FasL, ${ }^{67}$ decreased $\mathrm{Bcl}-2$ and $\mathrm{Bcl}-\mathrm{XL}$ expression, ${ }^{68}$ increased PD-1 expression, ${ }^{69}$ and undergo apoptosis by both caspase-dependent or -independent mechanisms. Endogenous Nef produced in infected cells can cause lysosomal permeabilization, with release of cathepsin-D into the cytosol and consequent outer mitochondrial membrane rupture. $^{70}$ Nef is also secreted from HIVinfected cells via exosomes. ${ }^{71}$ Exogenous administration of Nef to uninfected CD4T cells results in Fas-independent apoptosis, possibly by associating directly with the T-cell receptor, CXCR4 and SDF- $1 \alpha^{72}$ to induce apoptosis through unknown mechanisms.

However, not all in vitro effects of Nef are proapoptotic. Nef can directly interact with and inhibit the proapoptotic serine/ threonine kinase ASK $-1^{73}$ as well as $\mathrm{p} 53,{ }^{74}$ and can lead to inhibitory phosphorylation of the proapoptotic protein Bad by p21-activated kinase. ${ }^{75}$ Nef also inhibits apoptosis in HIVinfected monocyte-derived macrophages through phosphorylation of Bad. ${ }^{76}$

An overall in vivo proapoptotic effect of Nef, though, is suggested by animal models of HIV. Treatment of mice with Nef-derived peptides leads to increased CD4T-cell apoptosis compared with untreated mice, ${ }^{77}$ and transgenic mice that express human CD4 and HIV proteins develop an AIDS-like illness that is dependent on Nef. ${ }^{78}$ SIV Nef, on the other hand, increases Bcl-2 expression in transfected Jurkat cells compared with non-transfected cells, and inhibits cell cycle progression and Fas-mediated apoptosis. ${ }^{79}$ In non-pathogenic SIV infection, Nef may function to downmodulate the TCR to prevent activation-induced cell death. ${ }^{80}$

Vpr and apoptosis. HIV Vpr is an accessory, virionassociated protein with many functions, including induction of $\mathrm{G}(2) / \mathrm{M}$ cell cycle arrest upon infection of the cell. The mechanisms of $\mathrm{G}(2)$ arrest by $\mathrm{Vpr}$, induction of apoptosis and contribution to the immunopathogenesis of HIV infection have been reviewed extensively recently. ${ }^{81}$ Briefly, Vpr's in vitro pleiotropic effects on apoptosis are species, cell type, and concentration dependent, and vary based on HIV subtype and whether the TCR has been activated or not. ${ }^{82}$ $\mathrm{Vpr}$ expressed in low levels early after infection is antiapoptotic via suppression of NF- $\kappa \mathrm{B}$-dependent proinflammatory cytokine production, ${ }^{82}$ as well as upregulation of $\mathrm{Bcl}-2$ and downregulation of $\mathrm{Bax}^{83}$ However, later, after G(2) arrest, Vpr can induce apoptosis by binding to either Bax or ANT and VDAC in the mitochondrial membrane, causing release of cytochrome $c$ and activation of caspases 9 and $3 .^{84} \mathrm{Vpr}$ expression in CD4T cells also results in increased expression of NKG2D ligands, rendering infected CD4T cells susceptible to NK-cell-mediated killing. ${ }^{85}$

The contribution of $\mathrm{Vpr}$ to CD4T-cell loss in vivo was supported early by the demonstration of extracellular Vpr in serum from HIV-infected patients. Mice transgenic for the HIV-1 Vpr gene show enhanced CD4T-cell apoptosis compared with wild-type mice. Also, the R77Q polymorphism in Vpr, which is associated with decreased apoptotic-inducing ability in vitro, is overrepresented in LTNPs compared with typical progressors. ${ }^{11}$ Ex vivo infection of human lymphoid tissue with R5-tropic HIV with directed mutation at R77Q exhibits decreased CD4T-cell apoptosis compared with wildtype virus. ${ }^{86}$ The proapoptotic potential of HIV-1 Vpr is being exploited in preclinical studies on various types of cancer.

HIV protease and apoptosis. In the life cycle of the virus, the HIV protease cleaves the Gag/Pol polyprotein into functional subunits for production, maturation and budding of new virions. In vitro expression models demonstrate that HIV protease also has the ability to cleave several cellular targets to induce apoptosis, including Bcl-2. ${ }^{87}$ Our lab has demonstrated that the HIV protease is also able to cleave procaspase 8 to generate a proapoptotic cleavage fragment $41 \mathrm{kDa}$ in size - Casp8p41 - both in vitro and in vivo. ${ }^{88}$ Casp8p41 is able to induce apoptosis in infected CD4T cells via a mitochondrial dependent pathway, ${ }^{89}$ although the exact target on the mitochondria for its effect has yet to be identified. T cells expressing a procaspase 8 engineered to be resistant to HIV protease cleavage are resistant to apoptosis upon infection with HIV, suggesting that this mechanism is necessary for apoptosis of HIV-infected cells. ${ }^{90}$

\section{Future Directions and Unanswered Questions}

Many fundamental questions remain regarding apoptosis in the immunopathogenesis of HIV infection. Does apoptosis occur chiefly in infected cells or uninfected bystander cells in clinical HIV infection? Answering this question is of paramount importance if one is to either pharmacologically enhance or inhibit apoptosis. It is likely that apoptosis is occurring to some degree in both cellular populations, and thus further research is needed to find heretofore undiscovered regulators of apoptosis that are altered in productively and latently HIVinfected cells compared with uninfected cells that could serve as novel targets for intervention. Of the many mechanisms of HIV-induced apoptosis demonstrated in in vitro and in vivo models, which ones actually exist and are clinically relevant in human infection? If one attempts to inhibit one particular apoptotic pathway in bystander cells, will that drive the emergence of an alternative pathway to the same end? Are there clinically relevant biomarkers of ongoing-apoptotic activity, viral apoptosis-inducing ability, or host apoptosis susceptibility, which can be used to predict disease progression, response to antiviral therapy, or development of antiviral resistance? As effective preventive strategies, either with vaccination or microbicide, are lacking, viral-specific targets for development of new classes of antiviral therapy are dwindling, and drug resistance is rising; there is urgent need to address these fundamental issues in HIV pathogenesis. 


\section{Conflict Of interest}

The authors declare no conflict of interest.

Acknowledgements. Dr. Andrew Badley is supported by a grant from the National Institutes of Health (R01 Al62261). Dr. Nathan Cummins is supported by a Ruth L. Kirschstein National Research Service Award (DK007013-32) and a National Institutes of Health grant (AR 056950-02). We apologize to the many researchers in the field for whom we were unable to cite their work because space constraints for this manuscript. Selected additional references are available as Supplementary text to this manuscript.

1. Diaz M, Douek DC, Valdez H, Hill BJ, Peterson D, Sanne I et al. T cells containing T cell receptor excision circles are inversely related to HIV replication and are selectively and rapidly released into circulation with antiretroviral treatment. Aids 2003; 17: 1145-1149.

2. Dion ML, Poulin JF, Bordi R, Sylvestre M, Corsini R, Kettaf $\mathrm{N}$ et al. HIV infection rapidly induces and maintains a substantial suppression of thymocyte proliferation. Immunity 2004; 21: 757-768.

3. Rothen M, Gratzl S, Hirsch HH, Moroni C. Apoptosis in HIV-infected individuals is an early marker occurring independently of high viremia. AIDS Res Hum Retroviruses 1997; 13: 771-779.

4. Finkel TH, Tudor-Williams G, Banda NK, Cotton MF, Curiel T, Monks $C$ et al. Apoptosis occurs predominantly in bystander cells and not in productively infected cells of HIV- and SIV-infected lymph nodes. Nat Med 1995; 1: 129-134.

5. Wang L, Chen JJ, Gelman BB, Konig R, Cloyd MW. A novel mechanism of CD4 lymphocyte depletion involves effects of HIV on resting lymphocytes: induction of lymph node homing and apoptosis upon secondary signaling through homing receptors. J Immunol 1999; 162: 268-276.

6. Lecureuil C, Combadiere B, Mazoyer E, Bonduelle O, Samri A, Autran B et al. Trapping and apoptosis of novel subsets of memory T lymphocytes expressing CCR6 in the spleen of HIV-infected patients. Blood 2007; 109: 3649-3657.

7. Silvestri G, Sodora DL, Koup RA, Paiardini M, O'Neil SP, McClure HM et al. Nonpathogenic SIV infection of sooty mangabeys is characterized by limited bystander immunopathology despite chronic high-level viremia. Immunity 2003; 18: 441-452.

8. Pandrea I, Sodora DL, Silvestri G, Apetrei C. Into the wild: simian immunodeficiency virus (SIV) infection in natural hosts. Trends Immunol 2008; 29: 419-428.

9. Bosinger SE, Li Q, Gordon SN, Klatt NR, Duan L, Xu L et al. Global genomic analysis reveals rapid control of a robust innate response in SIV-infected sooty mangabeys. J Clin Invest 2009; 119: 3556-3572.

10. Bottarel F, Bonissoni S, Lucia MB, Bragardo M, Bensi T, Buonfiglio D et al. Decreased function of Fas in patients displaying delayed progression of HIV-induced immune deficiency. Hematol J 2001; 2: 220-227.

11. Lum JJ, Cohen OJ, Nie Z, Weaver JG, Gomez TS, Yao XJ et al. Vpr R77Q is associated with long-term nonprogressive HIV infection and impaired induction of apoptosis. $J$ Clin Invest 2003; 111: 1547-1554.

12. Herbeuval JP, Nilsson J, Boasso A, Hardy AW, Kruhlak MJ, Anderson SA et al. Differential expression of IFN-alpha and TRAIL/DR5 in lymphoid tissue of progressor versus nonprogressor HIV-1-infected patients. Proc Natl Acad Sci USA 2006; 103: 7000-7005.

13. Accornero P, Radrizzani M, Delia D, Gerosa F, Kurrle R, Colombo MP. Differential susceptibility to HIV-GP120-sensitized apoptosis in CD4+ T-cell clones with different T-helper phenotypes: role of CD95/CD95 L interactions. Blood 1997; 89: 558-569.

14. Ji J, Cloyd MW. HIV-1 binding to CD4 on CD4+CD25+ regulatory T cells enhances their suppressive function and induces them to home to, and accumulate in, peripheral and mucosal lymphoid tissues: an additional mechanism of immunosuppression. Int Immunol 2009; 21: 283-294.

15. Allers K, Loddenkemper C, Hofmann J, Unbehaun A, Kunkel D, Moos V et al. Gut mucosal FOXP3+ regulatory $C D 4+T$ cells and nonregulatory $C D 4+T$ cells are differentially affected by simian immunodeficiency virus infection in rhesus macaques. J Virol 2010; 84: 3259-3269.

16. Brenchley JM, Paiardini M, Knox KS, Asher Al, Cervasi B, Asher TE et al. Differential Th17 CD4 T-cell depletion in pathogenic and nonpathogenic lentiviral infections. Blood 2008: 112: $2826-2835$

17. Dianzani U, Bensi T, Savarino A, Sametti S, Indelicato M, Mesturini R et al. Role of FAS in HIV infection. Curr HIV Res 2003; 1: 405-417.

18. Mitra D, Steiner M, Lynch DH, Staiano-Coico L, Laurence J. HIV-1 upregulates Fas ligand expression in CD4+ T cells in vitro and in vivo: association with Fas-mediated apoptosis and modulation by aurintricarboxylic acid. Immunology 1996; 87: 581-585.

19. Kottilil S, Jackson JO, Reitano KN, O'Shea MA, Roby G, Lloyd M et al. Innate immunity in HIV infection: enhanced susceptibility to CD95-mediated natural killer cell death and turnover induced by HIV viremia. J Acquir Immune Defic Syndr 2007; 46: 151-159.

20. Li Q, Smith AJ, Schacker TW, Carlis JV, Duan L, Reilly CS et al. Microarray analysis of lymphatic tissue reveals stage-specific, gene expression signatures in HIV-1 infection. J Immunol 2009; 183: 1975-1982.
21. Badley AD, McElhinny JA, Leibson PJ, Lynch DH, Alderson MR, Paya CV. Upregulation of Fas ligand expression by human immunodeficiency virus in human macrophages mediates apoptosis of uninfected T lymphocytes. J Virol 1996; 70: 199-206.

22. Patki AH, Georges DL, Lederman MM. CD4+-T-cell counts, spontaneous apoptosis, and Fas expression in peripheral blood mononuclear cells obtained from human immunodeficiency virus type 1-infected subjects. Clin Diagn Lab Immunol 1997; 4: 736-741.

23. Gougeon ML, Lecoeur H, Boudet F, Ledru E, Marzabal S, Boullier S et al. Lack of chronic immune activation in HIV-infected chimpanzees correlates with the resistance of $T$ cells to Fas/Apo-1 (CD95)-induced apoptosis and preservation of a T helper 1 phenotype. $J$ Immunol 1997; 158: 2964-2976.

24. Sasaki Y, Ami Y, Nakasone T, Shinohara K, Takahashi E, Ando S et al. Induction of CD95 ligand expression on $T$ lymphocytes and B lymphocytes and its contribution to apoptosis of CD95-up-regulated CD4+ $T$ lymphocytes in macaques by infection with a pathogenic simian/human immunodeficiency virus. Clin Exp Immunol 2000; 122: 381-389.

25. Salvato MS, Yin CC, Yagita H, Maeda T, Okumura K, Tikhonov I et al. Attenuated disease in SIV-infected macaques treated with a monoclonal antibody against FasL. Clin Dev Immunol 2007; 2007: 93462.

26. Herbein G, Khan KA. Is HIV infection a TNF receptor signalling-driven disease? Trends Immunol 2008; 29: 61-67.

27. Vandergeeten C, Quivy V, Moutschen M, Van Lint C, Piette J, Legrand-Poels S. HIV-1 protease inhibitors do not interfere with provirus transcription and host cell apoptosis induced by combined treatment TNF-alpha + TSA. Biochem Pharmacol 2007; 73 1738-1748.

28. Herbeuval JP, Boasso A, Grivel JC, Hardy AW, Anderson SA, Dolan MJ et al. TNF-related apoptosis-inducing ligand (TRAIL) in HIV-1-infected patients and its in vitro production by antigen-presenting cells. Blood 2005; 105: 2458-2464.

29. Lichtner M, Maranon C, Vidalain PO, Azocar O, Hanau D, Lebon P et al. HIV type 1 -infected dendritic cells induce apoptotic death in infected and uninfected primary CD4T lymphocytes. AIDS Res Hum Retroviruses 2004; 20: 175-182.

30. Herbeuval JP, Nilsson J, Boasso A, Hardy AW, Vaccari M, Cecchinato V et al. HAART reduces death ligand but not death receptors in lymphoid tissue of HIV-infected patients and simian immunodeficiency virus-infected macaques. Aids 2009; 23: $35-40$.

31. Miura $Y$, Misawa N, Maeda N, Inagaki $Y$, Tanaka $Y$, Ito M et al. Critical contribution of tumor necrosis factor-related apoptosis-inducing ligand (TRAIL) to apoptosis of human CD4+ T cells in HIV-1-infected hu-PBL-NOD-SCID mice. J Exp Med 2001; 193: 651-660.

32. Lum JJ, Pilon AA, Sanchez-Dardon J, Phenix BN, Kim JE, Mihowich J et al. Induction of cell death in human immunodeficiency virus-infected macrophages and resting memory CD4T cells by TRAIL/Apo2I. J Virol 2001; 75: 11128-11136.

33. Shepard BD, De Forni D, McNamara DR, Foli A, Rizza SA, Abraham RS et al. Beneficial effect of TRAIL on HIV burden, without detectable immune consequences. PLOS One 2008; 3: e3096.

34. Gascon RL, Narvaez AB, Zhang R, Kahn JO, Hecht FM, Herndier BG et al. Increased HLA-DR expression on peripheral blood monocytes in subsets of subjects with primary HIV infection is associated with elevated CD4 T-cell apoptosis and CD4 T-cell depletion. J Acquir Immune Defic Syndr 2002; 30: 146-153.

35. Petrovas C, Chaon B, Ambrozak DR, Price DA, Melenhorst JJ, Hill BJ et al. Differential association of programmed death-1 and CD57 with ex vivo survival of CD8+ T cells in HIV infection. J Immunol 2009; 183: 1120-1132.

36. Jiao $\mathrm{Y}$, Fu J, Xing $\mathrm{S}$, Fu B, Zhang $\mathrm{Z}$, Shi $\mathrm{M}$ et al. The decrease of regulatory $T$ cells correlates with excessive activation and apoptosis of $\operatorname{CD} 8(+) T$ cells in HIV-1-infected typical progressors, but not in long-term non-progressors. Immunology 2009; 128(Suppl 1): e366-e375.

37. Brenchley JM, Price DA, Schacker TW, Asher TE, Silvestri G, Rao S et al. Microbial translocation is a cause of systemic immune activation in chronic HIV infection. Nat Med 2006: 12: 1365-1371.

38. Funderburg N, Luciano AA, Jiang W, Rodriguez B, Sieg SF, Lederman MM. Toll-like receptor ligands induce human $\mathrm{T}$ cell activation and death, a model for HIV pathogenesis. PLoS One 2008; 3: e1915.

39. Said EA, Dupuy FP, Trautmann L, Zhang Y, Shi Y, El-Far M et al. Programmed death-1induced interleukin-10 production by monocytes impairs $\mathrm{CD} 4(+) \mathrm{T}$ cell activation during HIV infection. Nat Med 2010; 16: 452-459.

40. Oyaizu N, McCloskey TW, Than S, Hu R, Kalyanaraman VS, Pahwa S. Cross-linking of CD4 molecules upregulates Fas antigen expression in lymphocytes by inducing interferongamma and tumor necrosis factor-alpha secretion. Blood 1994; 84: 2622-2631.

41. Szawlowski PW, Hanke T, Randall RE. Sequence homology between HIV-1 gp120 and the apoptosis mediating protein Fas. Aids 1993; 7: 1018.

42. Lum JJ, Schnepple DJ, Badley AD. Acquired T-cell sensitivity to TRAIL mediated killing during HIV infection is regulated by CXCR4-gp120 interactions. Aids 2005; 19: 1125-1133.

43. Kolesnitchenko V, Wahl LM, Tian H, Sunila I, Tani Y, Hartmann DP et al. Human immunodeficiency virus 1 envelope-initiated G2-phase programmed cell death. Proc Natl Acad Sci USA 1995; 92: 11889-11893.

44. Radrizzani M, Accornero P, Delia D, Kurrle R, Colombo MP. Apoptosis induced by HIVgp120 in a Th1 clone involves the generation of reactive oxygen intermediates downstream CD95 triggering. FEBS Lett 1997; 411: 87-92. 
45. Hashimoto F, Oyaizu N, Kalyanaraman VS, Pahwa S. Modulation of Bcl-2 protein by CD4 cross-linking: a possible mechanism for lymphocyte apoptosis in human immunodeficiency virus infection and for rescue of apoptosis by interleukin-2. Blood 1997; 90: 745-753.

46. Castedo M, Ferri KF, Blanco J, Roumier T, Larochette N, Barretina J et al. Human immunodeficiency virus 1 envelope glycoprotein complex-induced apoptosis involves mammalian target of rapamycin/FKBP12-rapamycin-associated protein-mediated p53 phosphorylation. J Exp Med 2001; 194: 1097-1110.

47. Perfettini JL, Roumier T, Castedo M, Larochette N, Boya P, Raynal B et al. NF-kappaB and p53 are the dominant apoptosis-inducing transcription factors elicited by the HIV-1 envelope. J Exp Med 2004; 199: 629-640.

48. Trushin SA, Algeciras-Schimnich A, Vlahakis SR, Bren GD, Warren S, Schnepple DJ et al Glycoprotein 120 binding to CXCR4 causes p38-dependent primary T cell death that is facilitated by, but does not require cell-associated CD4. J Immunol 2007; 178: 4846-4853.

49. Vendeville A, Rayne F, Bonhoure A, Bettache N, Montcourrier P, Beaumelle B. HIV-1 Ta enters $T$ cells using coated pits before translocating from acidified endosomes and eliciting biological responses. Mol Biol Cell 2004; 15: 2347-2360

50. Gibellini D, Caputo A, Celeghini C, Bassini A, La Placa M, Capitani S et al. Tat-expressing Jurkat cells show an increased resistance to different apoptotic stimuli, including acute human immunodeficiency virus-type 1 (HIV-1) infection. Br J Haematol 1995; 89: 24-33.

51. Gibellini D, Re MC, Ponti C, Maldini C, Celeghini C, Cappellini A et al. HIV-1 Tat protects CD4+ Jurkat T lymphoblastoid cells from apoptosis mediated by TNF-related apoptosisinducing ligand. Cell Immunol 2001; 207: 89-99.

52. Gibellini D, Re MC, Ponti C, Vitone F, Bon I, Fabbri G et al. HIV-1 Tat protein concomitantly down-regulates apical caspase-10 and up-regulates c-FLIP in lymphoid T cells: a potentia molecular mechanism to escape TRAIL cytotoxicity. J Cell Physiol 2005; 203: 547-556.

53. Westendorp MO, Frank R, Ochsenbauer C, Stricker K, Dhein J, Walczak H et al. Sensitization of T cells to CD95-mediated apoptosis by HIV-1 Tat and gp120. Nature 1995; 375 (6531): 497-500.

54. Bartz SR, Emerman M. Human immunodeficiency virus type 1 Tat induces apoptosis and increases sensitivity to apoptotic signals by up-regulating FLICE/caspase-8. J Virol 1999; 73: 1956-1963.

55. Sastry KJ, Marin MC, Nehete PN, McConnell K, el-Naggar AK, McDonnell TJ. Expression of human immunodeficiency virus type I tat results in down-regulation of bcl-2 and induction of apoptosis in hematopoietic cells. Oncogene 1996; 13: 487-493.

56. Minami R, Yamamoto M, Takahama S, Miyamura T, Watanabe H, Suematsu E. RCAS induced by HIV-Tat is involved in the apoptosis of HIV-1 infected and uninfected CD4+ T cells. Cell Immunol 2006; 243: 41-47.

57. Gulow K, Kaminski M, Darvas K, Suss D, Li-Weber M, Krammer PH. HIV-1 trans-activator of transcription substitutes for oxidative signaling in activation-induced $\mathrm{T}$ cell death. $J$ Immunol 2005; 174: 5249-5260.

58. Chen D, Wang M, Zhou S, Zhou Q. HIV-1 Tat targets microtubules to induce apoptosis, a process promoted by the pro-apoptotic Bcl-2 relative Bim. EMBO J 2002; 21: 6801-6810.

59. Zauli G, Gibellini D. The human immunodeficiency virus type-1 (HIV-1) Tat protein and Bcl-2 gene expression. Leuk Lymphoma 1996; 23 (5-6): 551-560.

60. Yang Y, Tikhonov I, Ruckwardt TJ, Djavani M, Zapata JC, Pauza CD et al. Monocytes treated with human immunodeficiency virus Tat kill uninfected CD4(+) cells by a tumor necrosis factor-related apoptosis-induced ligand-mediated mechanism. J Virol 2003; 77 6700-6708.

61. Ehret A, Westendorp MO, Herr I, Debatin KM, Heeney JL, Frank R et al. Resistance of chimpanzee $T$ cells to human immunodeficiency virus type 1 Tat-enhanced oxidative stress and apoptosis. J Virol 1996; 70: 6502-6507.

62. Kim N, Dabrowska A, Jenner RG, Aldovini A. Human and simian immunodeficiency virusmediated upregulation of the apoptotic factor TRAIL occurs in antigen-presenting cells from AIDS-susceptible but not from AIDS-resistant species. J Virol 2007; 81: 7584-7597.

63. Casella CR, Rapaport EL, Finkel TH. Vpu increases susceptibility of human immunodeficiency virus type 1-infected cells to fas killing. J Virol 1999; 73: 92-100.

64. Akari H, Bour S, Kao S, Adachi A, Strebel K. The human immunodeficiency virus type 1 accessory protein $\mathrm{Vpu}$ induces apoptosis by suppressing the nuclear factor kappaBdependent expression of antiapoptotic factors. J Exp Med 2001; 194: 1299-1311.

65. Rucker E, Grivel JC, Munch J, Kirchhoff F, Margolis L. Vpr and Vpu are important for efficient human immunodeficiency virus type 1 replication and CD4+ T-cell depletion in human lymphoid tissue ex vivo. J Virol 2004; 78: 12689-12693.

66. Hill MS, Ruiz A, Pacyniak E, Pinson DM, Culley N, Yen B et al. Modulation of the severe CD4+ T-cell loss caused by a pathogenic simian-human immunodeficiency virus by replacement of the subtype B vpu with the vpu from a subtype C HIV-1 clinical isolate. Virology 2008; 371: 86-97.

67. Zauli G, Gibellini D, Secchiero P, Dutartre H, Olive D, Capitani S et al. Human immunodeficiency virus type $1 \mathrm{Nef}$ protein sensitizes CD4(+) T lymphoid cells to apoptosis via functional upregulation of the CD95/CD95 ligand pathway. Blood 1999; 93: 1000-1010.

68. Rasola A, Gramaglia D, Boccaccio C, Comoglio PM. Apoptosis enhancement by the HIV-1 Nef protein. J Immunol 2001; 166: 81-88.

69. Muthumani K, Choo AY, Shedlock DJ, Laddy DJ, Sundaram SG, Hirao L et al. Human immunodeficiency virus type 1 Nef induces programmed death 1 expression

through a p38 mitogen-activated protein kinase-dependent mechanism. J Virol 2008; 82 11536-11544

70. Laforge M, Petit F, Estaquier J, Senik A. Commitment to apoptosis in CD4(+) $\mathrm{T}$ lymphocytes productively infected with human immunodeficiency virus type 1 is initiated by lysosomal membrane permeabilization, itself induced by the isolated expression of the viral protein Nef. J Virol 2007; 81: 11426-11440.

71. Lenassi M, Cagney G, Liao M, Vaupotic T, Bartholomeeusen K, Cheng Y et al. HIV Nef is secreted in exosomes and triggers apoptosis in bystander CD4+ T cells. Traffic 2009; 11: 110-122.

72. James CO, Huang MB, Khan M, Garcia-Barrio M, Powell MD, Bond VC. Extracellular Nef protein targets $\mathrm{CD} 4+\mathrm{T}$ cells for apoptosis by interacting with CXCR4 surface receptors. $J$ Virol 2004; 78: 3099-3109.

73. Geleziunas R, Xu W, Takeda K, Ichijo H, Greene WC. HIV-1 Nef inhibits ASK1-dependent death signalling providing a potential mechanism for protecting the infected host cell. Nature 2001; 410 (6830): 834-838.

74. Greenway AL, McPhee DA, Allen K, Johnstone R, Holloway G, Mills $\mathrm{J}$ et al. Human immunodeficiency virus type 1 Nef binds to tumor suppressor p53 and protects cells against p53-mediated apoptosis. J Virol 2002; 76: 2692-2702.

75. Wolf D, Witte V, Laffert B, Blume K, Stromer E, Trapp S et al. HIV-1 Nef associated PAK and PI3-kinases stimulate Akt-independent Bad-phosphorylation to induce anti-apoptotic signals. Nat Med 2001; 7: 1217-1224.

76. Olivetta E, Federico M. HIV-1 Nef protects human-monocyte-derived macrophages from HIV-1-induced apoptosis. Exp Cell Res 2006; 312: 890-900.

77. Huang MB, James CO, Powell MD, Bond VC. Apoptotic peptides derived from HIV-1 Nef induce lymphocyte depletion in mice. Ethn Dis 2008; 18(2 Suppl 2): S2-30-37.

78. Priceputu E, Rodrigue I, Chrobak P, Poudrier J, Mak TW, Hanna Z et al. The Nef-mediated AIDS-like disease of $\mathrm{CD} 4 \mathrm{C} /$ human immunodeficiency virus transgenic mice is associated with increased Fas/FasL expression on T cells and T-cell death but is not prevented in Fas-, FasL-, tumor necrosis factor receptor 1-, or interleukin-1beta-converting enzyme-deficient or Bcl2-expressing transgenic mice. J Virol 2005; 79: 6377-6391.

79. Ndolo T, Dhillon NK, Nguyen H, Guadalupe M, Mudryj M, Dandekar S. Simian immunodeficiency virus Nef protein delays the progression of CD4+ T cells through $\mathrm{G} 1 / \mathrm{S}$ phase of the cell cycle. J Virol 2002; 76: 3587-3595.

80. Schindler M, Schmokel J, Specht A, Li H, Munch J, Khalid M et al. Inefficient Nef-mediated downmodulation of CD3 and MHC-I correlates with loss of CD4+T cells in natural SIV infection. PLOS Pathog 2008; 4: e1000107.

81. Majumder B, Venkatachari NJ, Srinivasan A, Ayyavoo V. HIV-1 mediated immune pathogenesis: spotlight on the role of viral protein R (Vpr). Curr HIV Res 2009; 7: 169-177.

82. Ayyavoo V, Mahboubi A, Mahalingam S, Ramalingam R, Kudchodkar S, Williams WV et al. HIV-1 Vpr suppresses immune activation and apoptosis through regulation of nuclear factor kappa B. Nat Med 1997; 3: 1117-1123.

83. Conti L, Rainaldi G, Matarrese P, Varano B, Rivabene R, Columba $S$ et al. The HIV-1 vpr protein acts as a negative regulator of apoptosis in a human lymphoblastoid T cell line: possible implications for the pathogenesis of AIDS. J Exp Med 1998; 187: 403-413.

84. Jacotot E, Ravagnan L, Loeffler M, Ferri KF, Vieira HL, Zamzami N et al. The HIV-1 viral protein $\mathrm{R}$ induces apoptosis via a direct effect on the mitochondrial permeability transition pore. J Exp Med 2000; 191: 33-46.

85. Richard J, Sindhu S, Pham TN, Belzile JP, Cohen EA. HIV-1 Vpr up-regulates expression of ligands for the activating NKG2D receptor and promotes NK cell-mediated killing. Blood 2010; 115: 1354-1363.

86. Rajan D, Wildum S, Rucker E, Schindler M, Kirchhoff F. Effect of R77Q, R77A and R80A changes in Vpr on HIV-1 replication and CD4T cell depletion in human lymphoid tissue ex vivo. Aids 2006; 20: 831-836.

87. Strack PR, Frey MW, Rizzo CJ, Cordova B, George HJ, Meade R et al. Apoptosis mediated by HIV protease is preceded by cleavage of Bcl-2. Proc Natl Acad Sci USA 1996; 93: 9571-9576.

88. Nie Z, Bren GD, Vlahakis SR, Schimnich AA, Brenchley JM, Trushin SA et al. Human immunodeficiency virus type 1 protease cleaves procaspase 8 in vivo. J Virol 2007; 81: 6947-6956.

89. Algeciras-Schimnich A, Belzacq-Casagrande AS, Bren GD, Nie Z, Taylor JA, Rizza SA et al. Analysis of HIV protease killing through caspase 8 reveals a novel interaction between caspase 8 and mitochondria. Open Virol J 2007; 1: 39-46.

90. Nie Z, Bren GD, Rizza SA, Badley AD. HIV protease cleavage of procaspase 8 is necessary for death of HIV-infected cells. Open Virol J 2008; 2: 1-7.

(c)

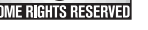
under the Creative Commons Attribution-Noncommercial-No Derivative Works 3.0 Unported License. To view a copy of this license, visit http://creativecommons.org/licenses/by-nc-nd/3.0/

\section{Supplementary Information accompanies the paper on Cell Death and Disease website (http://www.nature.com/cddis)}

